\title{
Dating Mantle Metasomatism: U-Pb Geochronology of zircons in cratonic mantle xenoliths from Montana and Tanzania
}

\author{
Rudnick, R.L. ${ }^{1}$, Ireland, T.R. 2,3 , Gehrels, G. ${ }^{4}$, Irving, A.J.5 ${ }^{5}$ Chesley, J.T. ${ }^{4}$ and Hanchar, J.M. ${ }^{6}$ \\ 1. Dept. of Earth and Planetary Sciences, Harvard University, 20 Oxford St., Cambridge, MA 02138, U.S.A. \\ 2. Research School of Earth Sciences, The Australian National University, Canberra, A.C.T. 0200, Australia \\ 3. Dept. of Geological and Environmental Sciences, Stanford University, Palo Alto, CA 94305-2215, U.S.A. \\ 4. Dept. of Geological Sciences, University of Arizona, Gould-Simpson Building, Tucson, AZ 85721, U.S.A. \\ 5. Dept. of Geological Sci., AJ-20, University of Washington, Seattle, WA 98195, U.S.A. \\ 6. Env. Res. Div., Argonne National Laboratory, 9700 South Cass Ave., Argonne, IL 60439, U.S.A.
}

Mantle metasomatism is prevalent in peridotite xenoliths carried in both alkali basalts and kimberlites. Metasomatized peridotites are characterized by incompatible element enrichments (large ion lithophile element and LREE enrichments \pm concomitant high field strength element enrichments) in otherwise refractory bulk compositions. These metasomatized peridotites also tend to have evolved isotopic compositions. Pinning down the timing of metasomatism is difficult due to the high temperatures at which most xenoliths equilibrated and the lower blocking temperatures of most isotopic systems. Without this age information it is difficult to interpret the isotopic compositions of metasomatized peridotites in terms of the origin of the metasomatic components.

We report here the results of U-Pb dating of zircon occurring as a metasomatic phase in harzburgites from the Highwood Mts., Montana, and from the Labait cinder cone, Tanzania. These ages pin down the timing of mantle metasomatism, which ranges from Proterozoic to Quaternary and in both cases coincides well with regional geological events.

\section{Samples}

The potassic maafic volcanics and intrusives in the Highwood Mountains represent Eocene postsubduction continental arc magmas within the Great Falls tectonic zone near the NW margin of the Archean Wyoming craton (O'Brien et al., 1995). The Great Falls tectonic zone is believed to represent a $1.8 \mathrm{Ga}$ tectonic boundary between the Wyoming and Hearne provinces (Hoffman, 1989) although details of its lithology and structure are largely obscured by sedimentary and volcanic cover. A large variety of ultramafic xenoliths are found in the Highwood minettes. Spinel harzburgite and lherzolite are the dominant lithologies and contain metasomatic minerals (e.g., mica, amphibole, ilmenite and apatite). Zircon occurs in 3 of the ultramafic xenoliths: within olivine in two olivine-rich harzburgites and in glimmerite veins cutting a harzburgite (two separate veins were analyzed). In addition, zircons from a mica gabbro (cpx-plag-phlogopite-apatite-monazite-zircon) were also analyzed.

In the olivine-rich harzburgites (EN88-4, EN89-1), zircon is associated with apatite and Mgilmenite. Mica and amphibole also occur in the harzburgites, which have low Mg\#s (e.g., $\mathrm{Mg} /(\mathrm{Mg}+\mathrm{Fe})=83$ ) compared to residual peridotite xenoliths. Zircons (10 to $100 \mu \mathrm{m}$ across) from the harzburgite are oval to round and in BSE and CL show patchy zoning, but no growth zoning. The glimmerites cutting harzburgite EN88-1 are surrounded by thick (several $\mathrm{cm}$ ) orthopyroxenite reaction zones, which also contain zircon. In addition to zircon, the glimmerite veins contain mica, orthopyroxene, clinopyroxene, rutile, magnetite, chromite and calcite \pm altered plagioclase (believed to be xenocrystic), monazite, apatite and thorianite. The harzburgite that they cut contains a small amount of mica and has $\mathrm{Mg} \#=88$, low compared to refractory peridotites. Zircon has not been observed in the harzburgite itself. Zircons from the glimmerite (50 to $500 \mu \mathrm{m}$ in longest dimension) are round to elongate and have a distinctive lavender color. BSE images reveal growth zoning in some of the crystals, indicative of crystallization from a melt. Zircons in the mica gabbro are relatively small $(30-80 \mu \mathrm{m})$, muti-facted spheres, similar to zircons from granulite facies xenoliths.

Based on thermobarometry, the harzburgites described above equilibrated at rather shallow levels in the upper mantle or lower crust. Their trace element compositions are peculiar for peridotites (LREE enriched, with large $\mathrm{Eu}, \mathrm{Sr}$ and $\mathrm{Nb}$ depletions) and are interpreted to reflect the composition 
of the metasomatic agent (melt or fluid), which appears to have affinities with the continental crust. They are some of the most isotopically evolved samples yet measured from the lithospheric mantle $\left(\varepsilon_{\mathrm{Nd}}=-9\right.$ to $-39,{ }^{87} \mathrm{Sr} /{ }^{86} \mathrm{Sr}=0.705$ to $0.759,{ }^{206 \mathrm{~Pb}} / 204 \mathrm{~Pb}=17.9$ to 23.2$)$ (Carlson and Irving, 1994), indicating their incompatible trace elements are dominated by a component that experienced long term enrichment of LREE, high $\mathrm{Rb} / \mathrm{Sr}$ and $\mathrm{U} / \mathrm{Pb}$.

The Labait tuff cone is an olivine melilitite that erupted on the eastern margin of the Archean Tanzanian craton where it meets Proterozoic rocks of the Usagaran belt (Dawson et al., 1997). The east African rift penetrates the edge of the craton here and Labait is part of the youngest episode of rift volcanism, dated elsewhere between 0.7 to $1.5 \mathrm{Ma}$ (Bagdasaryan et al., 1973). Xenoliths are abundant at Labait and include dunitic cumulates, spinel harzburgites, chromite harzburgites, garnet harzburgite and lherzolites (Dawson et al., 1997; Lee and Rudnick, 1998). Zircon was found in a phlogopite-rutile-sulfide vein in a chromite-harzburgite. These zircons are large (100 to $500 \mu \mathrm{m}$ ), euhedral, and show growth zoning in-BSE images.

\section{Results}

Zircons extracted from the Montana samples were measured on SHRIMP I and II at the Australian National University following the methods of Williams and Claesson (1987). The harzburgite zircons show a relatively simple age distribution (Fig. 1), yielding a mean age of $1784 \pm 14 \mathrm{Ma}$ (error quoted as $2 \sigma$ of the mean). In contrast, zircons from the glimmerite vein show a significant spread in ages between $\sim 1.7$ and $1.9 \mathrm{Ga}$. These zircons also show a range of ${ }^{238} \mathrm{U} / 206 \mathrm{~Pb}$ values, indicative of a small amount of modern $\mathrm{Pb}$ loss. There is no obvious correlation between zircon shape, structure or age. Multiple spots within single zircons generally yield the same ages; the maximum age difference within a single crystal is $50 \mathrm{Ma}$. Taking an average of all the data for glimmerite zircons yields an age of $1798 \pm 18 \mathrm{Ma}$. Zircons from both samples are thus the same age, within error, and correspond well with the age of monazite from the glimmerite vein (1806 1 $\mathrm{Ma}$, Carlson and Irving, 1994). We interpret this age as the time when the zircons grew from a melt that was also responsible for the crystallization of mica, amphibole, apatite and ilmenite. This is also likely the time when the LREE-enriched signature was imparted to these rocks. Both samples have strongly negative $\varepsilon_{\mathrm{Nd}}$ at the time of metasomatism (i.e., -8 to -9 , Carlson and Irving, 1994), suggesting that the metasomatic melt carried a time integrated LREE enriched signature. If one assumes an upper crustal-like $\mathrm{Sm} / \mathrm{Nd}$ ratio for the source of the fluid (e.g., ${ }^{147} \mathrm{Sm} /{ }^{144} \mathrm{Nd}=0.12$ ), then the $\mathrm{T}_{\mathrm{DM}}$ age of the source is $\sim 2.7 \mathrm{Ga}$. U-Pb ages for spot analyses of centers of zircons from the mica gabbro (Fig. 2) show a spread of concordant ages between 1.8 and $2.25 \mathrm{Ga}$, providing evidence for an older component compared to the ultramafic xenoliths. This sample may have crystallized at $\geq 2.25 \mathrm{Ga}$ and underwent high-grade metamorphism at $1.8 \mathrm{Ga}$, the timing of the metasomatism in the ultramafic xenoliths. Alternatively, the older zircons may be xenocrystic. There is no obvious morphology differences that are correlative with age.

Four zircon fractions from the Tanzanian harzburgite were analyzed by TIMS at the University of Arizona following the methods described in Gehrels (1990). These zircons are extremely young (Fig. 2), with a mean age of $400 \pm 200 \mathrm{Ka}$, demonstrating that the phlogopite metasomatism displayed by this xenolith is related to the rift magmatism. The date also constrains the age of the Labait volcano to be Pleistocene or younger.

\section{References}

Bagdasaryan, G. P., Gerasimovski, V. I., Polyakov, A. I., and Gukasyan, R. K., 1973, Age of volcanic rocks in the rift zones of East Africa: Geochem. Internat., v. 10, p. 66-71.

Carlson, R. W., and Irving, A. J., 1994, Depletion and enrichment history of subcontinental lithospheric mantle: An $\mathrm{Os}, \mathrm{Sr}, \mathrm{Nd}$ and $\mathrm{Pb}$ isotopic study of ultramafic xenoliths from the northwestern Wyoming Craton: Earth Planet. Sci. Lett., v. 126, p. 457-472. 
Dawson, J. B., James, D., Paslick, C., and Halliday, A. M., 1997, Ultrabasic potassic low-volume magmatism and continental rifting in north-central Tanzania: association with enhanced heat flow: Proc. Sixth Int. Kimberlite Conf., Russian Geology and Geophysics, v. 38, p. 69-81.

Gehrels, G. E., 1990, Late Proterozoic-Cambrian metamorphic basement of the Alexander terrane on Long and Dall Islands, southeast Alaska: Geol. Soc. Am. Bull., v. 102, p. 760-767.

Hoffman, P. F., 1989, Precambrian geology and tectonic history of North America, in Bally, A. W., and Palmer, A. R., eds., The Geology of North America -- an Overview: Boulder, Geol. Soc. Am., p. 447-512.

Lee, C.-T., and Rudnick, R. L., 1998, The origin and demise of cratonic lithosphere: a geochemical perspective from the Tanzanian craton: (this volume).

O'Brien, H. E., Irving, A. J., McCallum, I. S., and Thirlwall, M. F., 1995, Strontium, neodymium and lead isotopic evidence for the interaction of post-subduction asthenospheric potassic mafic magmas of the Highwood Mountains, Montana, USA, with ancient Wyoming craton lithospheric mantle: Geochim. Cosmochim. Acta, v. 59 , p. $4539-4562$.

Paslick, C., Halliday, A. N., James, D., and Dawson, J. B., 1995, Enrichment of the continental lithosphere by OIB melts; isotopic evidence from the volcanic province of northern Tanzania: Earth Planet. Sci. Lett., v. 130, p. $109-126$.

Stacey, J. S., and Kramers, J. D., 1975, Approximation of terrestrial lead isotope evolution by a two-stage model: Earth Planet. Sci. Lett., v. 26, p. 207-221.

Tera, F., and Wasserburg, G. J., 1972, U-Th-Pb systematics in three Apollo 14 basalts and the problem of initial $\mathrm{Pb}$ in lunar rocks: Earth Planet. Sci. Lett., v. 14, p. 281-304.

Williams, I. S., and Claesson, 1987, Isotopic evidence for the Precambrian provenance and Caledonian metamorphism of high grade paragneisses from the Seve Nappes, Scandinavian Caledonides; 2, Ion microprobe zircon U-Th-Pb: Contrib. Mineral. Petrol., v. 97, p. 205-217.
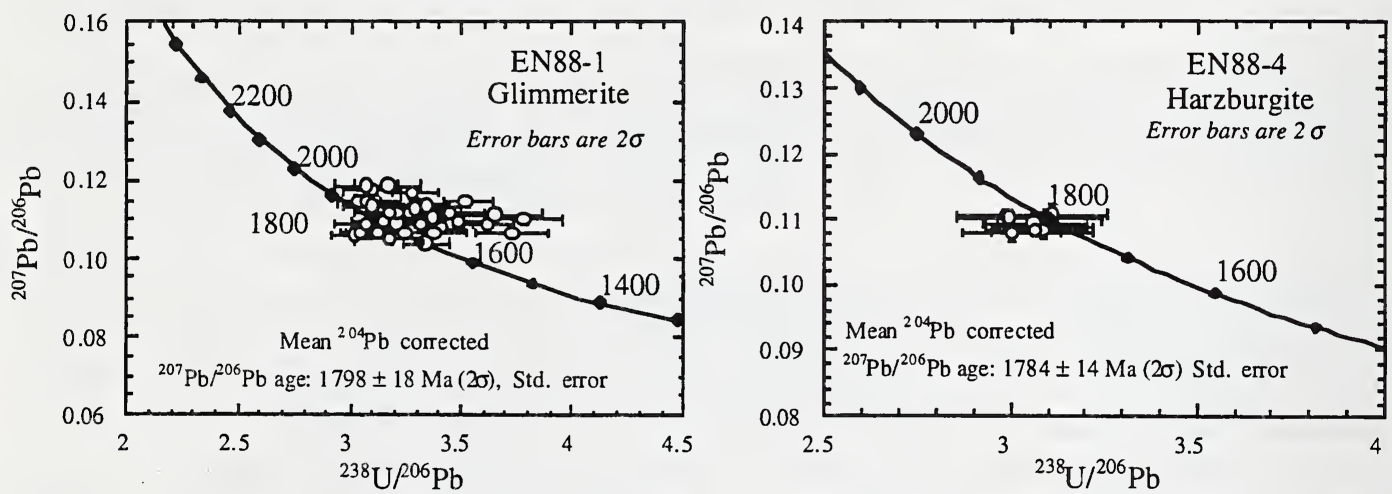

Figure 1. Tera-Wasserburg (1972) diagrams showing ages of individual spot analyses for zircons from two mantle xenoliths from the edge of the Wyoming craton, Highwood Mts., Montana. Labelled ages are in Ma.
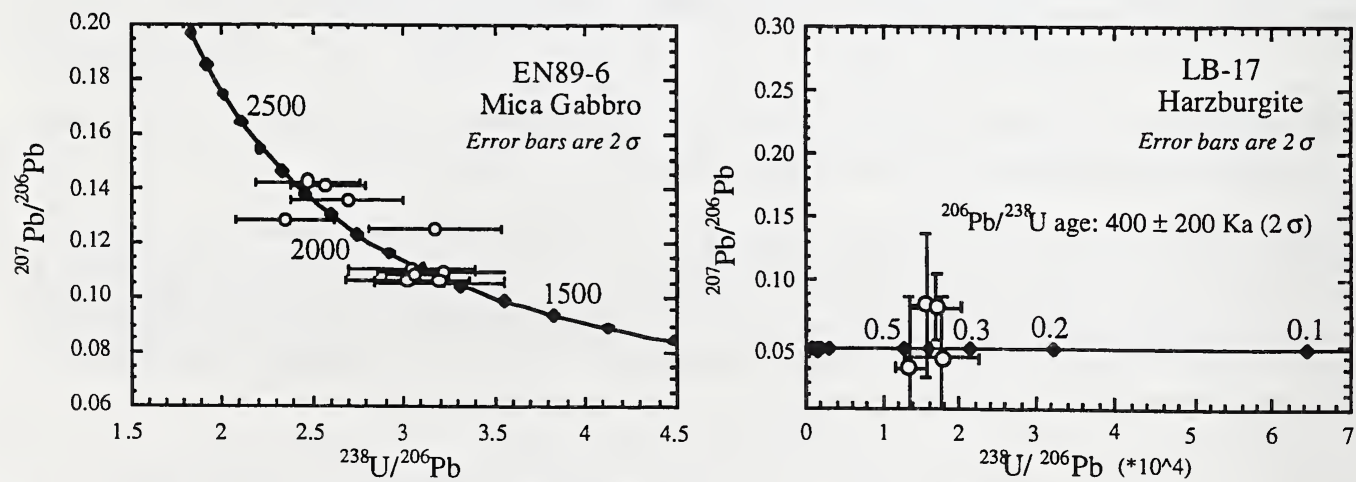

Figure 2. Tera-Wasserburg diagrams showing (left) ages of individual spot analyses for zircons from a mica gabbro xenolith from the Highwood Mts., Montana, and (right) ages of individual zircon fractions for zircons extracted from a harzburgite from Labait, Tanzania. Ages marked in Ma. Error on LB-17 is $2 \sigma$ and includes a range in common lead from 0 to $2 \mathrm{Ga}$ (Stacey and Kramers, 1975) and $\mathrm{Pb}$ for modern Tanzanian volcanics (Paslick et al., 1995) 